\title{
Limits to the equilibrating capabilities of market systems
}

\author{
Axel Leijonhufvud
}

Received: 28 September 2008 / Accepted: 8 April 2009 / Published online: 17 May 2009

(C) The Author(s) 2009. This article is published with open access at Springerlink.com

\begin{abstract}
Serious macroproblems are not a simple result of inflexibilities of prices. Standard economic theory does not help our understanding of the role of money and of monetary institutions in disturbed states of the economy. Several examples are discussed.
\end{abstract}

\section{Introduction}

My qualifications for speaking at an ESHIA conference are somewhat doubtful. I am obviously not an econophysicist and have done no actual agent-based modelling. I suspect I have been invited because I have been trying to promote work in these areas for a rather long time. In 1991, with the help of Masanao Aoki, John McCall and Vela Velupillai, I started a small Center for Computable Economics at UCLA. Quite a number of young people who later became prominent in Agent-based Economics gave seminars or attended conferences at CCE. This small Center eventually failed, however. When Masanao, John and I were induced by the university to take early retirement, our faculty could not be induced to continue the activity. Agent-based modelling was not yet reputable in the mid-1990s. As you know, its reputability in more mainstream quarters remains tenuous even today.

I belong to the last generation of economists who could do theory of sorts without fairly heavy mathematical equipment and not be laughed out of court for one's presumption. I thought the best thing to do with this lecture was to explain to you some of

Invited Lecture, ESHIA/WEHIA 2008 Conference, Warsaw University of Technology, June 19-21, 2008.

A. Leijonhufvud $(\varangle)$

UCLA and The University of Trento, Trento, Italy

e-mail: axel@ucla.edu 
the reasons why someone with my background came to promote work of a sort which I myself am not equipped to pursue.

\section{Micro and macro long ago}

The story goes back to the relationship between micro and macroeconomics almost fifty years ago. Macro at that time was "Keynesian" economics. It purported to explain unemployment. Micro was "price theory". It purported to explain how markets worked and how prices were determined. In micro, markets worked to coordinate activities. In macro, they did not. These two views of how the world works were reconciled, after a fashion, by the so-called "neoclassical synthesis" which proposed that market economies generally worked as explained in microeconomics except that prices in certain markets, and in particular in markets for labor, did not obey the "law of supply and demand". Keynesian economics was that special branch of general economic theory where wages did not decline in response to excess supply.

One problem with this view was that Keynes himself had definitely not assumed wages to be "rigid" (as it used to be called). But I have to come back to that later.

\section{Supply and demand}

The first thing a new-comer to economics encounters is likely to be the so-called "law of supply and demand". It is a phrase much used or misused and it is not clear what the so-called law is supposed to mean exactly, although questions of momentous social and political importance hinge on it. The simplest and probably most ancient version we recognize as a story of negative feedback control. Let me call it Version 1. Discrepancies between amounts demanded and supplied lead to changes in price which reduce the discrepancy and, plausibly, equilibrate the market. A great many economists believe that a system consisting of an arbitrary number of such markets must surely function in essentially the same way and that, if anything appears to go wrong, it must be because some sort of interference with the adjustment of prices.

Version 1 has some problems, however. For example, if price initially were such that supply exceeds demand, what will be the reaction of producers unable to sell what they had hoped for at that price? We may suppose that they reduce output. Now we have two adaptive processes going on at the same time. Price moves in response to excess demand and output moves in response to the discrepancy between market price and marginal cost. Call this Version 2. It is somewhat less reassuring than the first version. The two coupled oscillators will produce a non-linear process which need not converge nicely and could conceivably even be some sort of chaotic monster.

But that is not how markets normally behave. A Version 3 might start from noticing that Version 2 does not recognize the possibility that output and consumption are not continuously equal. Unless output is some sort of service that evaporates instantly if not consumed, the model should include inventories and show how they move over time. One might think, perhaps, that adding another difference or differential equation to the little system is likely to make its dynamic behaviour "worse", but a little reflection tells us instead that inventory management helps us understand why markets do not 
normally behave as Version 2 would suggest. The inventories act as buffer stocks which absorb the high frequency oscillations in sales and smooth the time-path of prices. The middlemen who hold the inventories act as market makers.

Version 3 is a bit better than Version 1, but this does not mean that the whole system of interrelated markets can be assumed to behave as a "representative market" of either Version. One reason is that markets operate on different time scales. It is only in general equilibrium models that decisions are constrained to be synchronized so that all prices (for example) are revised every time the time subscript "ticks up". In manufacturing, for example, output prices tend to be revised more frequently than wages. ${ }^{1}$ Decisions in one market are made on the basis of information produced in another market.

\section{Keynes}

Contrary to the neoclassical synthesis, Keynes did not assume that wages were "rigid" and unresponsive to the state of labor markets. He did assume that they were revised less frequently than output prices and that average wages moved more slowly than average prices. But if wages did respond to excess supply of labor, however slowly, why would not the usual market forces bring the economy to full employment? Something else than wage rigidity had to be wrong with the system.

What goes wrong, Keynes thought, stems from the fact that goods are not to be bought by offering goods. It is a monetary, not a barter system we are dealing with. "Goods buy money and money buys goods but goods do not buy goods" (Clower 1967). In Keynes's General Theory this leads to two problems.

First, if someone increases his saving today, this means a reduction in the demand for consumer goods today but no corresponding effective demand at some future date. It does not by itself send a signal for producers to move resources from the production of present goods to production of future goods, that is, to invest. However, the saver will buy a bond or some other interest bearing instruments and this should reduce the interest rate which is also a signal, albeit less direct, to increase investment. But this indirect signal may be interfered with. Speculators might stabilize the interest rate, for example. Keynes in his day blamed the Bank of England for holding the interest rate too high in order to defend the exchange rate of the pound sterling. The result was too little investment to absorb saving which meant excess supply in goods markets and unemployment. ${ }^{2}$ When unemployment is due to intertemporal prices being wrong, it will not be cured by falling wages. A rapid decline of wages and prices might in fact cause waves of bankruptcies and make matters far worse. It is fortunate, therefore, that labor markets work on a far different time-scale from exchange markets for example.

\footnotetext{
1 At long last we are learning quite a bit about the frequency of price revisions in various types of markets. For a survey of recent work, see Maćkowiak and Smets (2008).

2 In recent years, we have had an example of the opposite problem. An extreme low interest policy on part of the Federal Reserve created asset price inflation, too much investment in housing, and a serious deterioration in credit standards.
} 
Keynes's second problem is that the offer by the unemployed to work is not an effective demand for consumer goods. So the effect on output of the decline in investment is amplified by a secondary decline in consumption. This Keynesian multiplier effect is of particular interest because it brings into economic theory a deviationamplifying feedback loop entirely missing from neoclassical theory.

\section{Two worldviews}

We can now contrast two worldviews, if you will. One views the market system as entirely self-regulating; all feedback loops are deviation counteracting ... and it is supposed that nothing can go wrong with the world unless there is some sort of interference with the adjustment of prices. The other, Keynesian view sees the intertemporal coordination of saving and investment as a low probability event. And when it does not happen, deviation amplifying accelerator and multiplier effects take over. The economy requires the constant exercise of stabilization policy to function at all efficiently.

These two belief systems are of course inconsistent with one another. Neither one is plausible. The modern economy is the product of a long evolution. No such system would malfunction all of the time. Nor would it be completely incapable of malfunction. The self-regulating capabilities of all systems, whether man-made or natural, are bounded. The probability that among economic systems we might find an exception is surely zero.

Consider again the Keynesian multiplier. It is the most strikingly "anti-classical" property of his system. It assumes, however, that consumption depends closely on concurrent income. Fifty-some years ago, however, what were then called the "new" theories of the consumption function of Modigliani and Friedman showed consumption to depend on a slowly moving average of income. Households tend to smooth the time-path of consumption rather than make it track the fluctuations of their incomes. This drastically reduces the strength of the deviation-amplifying multiplier ${ }^{3}$ and makes it plausible that the deviation-counteracting price mechanisms will dominate the economy's response to shocks. The system's behaviour would be then be more or less neoclassical.

A hundred years ago, manufacturing workers lived more nearly hand-to-mouth and consequently seldom had the means to maintain their consumption standard during periods of unemployment. Today, unemployment compensation schemes buffer them to a considerable extent and workers in particularly cyclical industries are likely to be financially prepared for variations in employment. In addition, they may also have some access to credit. Thus one would expect strong Keynesian deviation-amplifying effects only in situations when these various buffer stocks were depleted or rendered in some way inoperable.

These considerations led me many years ago (Leijonhufvud 1973) to propose what came to be called the "corridor hypothesis", namely that the system had bounded

\footnotetext{
${ }^{3}$ If the assumptions of the rational expectations hypothesis were to be satisfied, the multiplier would be even smaller.
} 
homeostatic capabilities that under "normal" conditions would operate to move it towards a state where activities were well coordinated. However, if the economy was propelled outside these bounds, Keynesian properties would come to dominate and the system's ability to regain a highly coordinated state would be undermined. This kind of coordination failure would be unlikely to occur except in the wake of a financial crisis.

The corridor hypothesis basically implies that severe Keynesian recessions would be rare events. There is no well-defined statistical distribution for recessions so we can hardly call such recessions "fat tail" events. But the process which produces a severe recession of the Keynesian type may still contain a simple lesson for the understanding of such events, namely, that they occur when deviation amplifying feedback loops come to swamp the negative feedbacks that normally keep the system reasonably well organized.

\section{High inflations}

Some years later, I became interested in inflation theory. This interest began with the growing conviction that the standard inflation theory based on monetary general equilibrium models surely must be wrong. These models showed some distortion in resource allocation due to people's attempt to economize on the holding of money balances the purchasing power of which was declining. But this was basically the only source of welfare loss in this kind of theory. It hardly explained the strong aversion to inflation among people who have to live with it.

You may note that this remains the most widely accepted theory today. Curiously, it is held by all those economists who would have tight control of inflation be the exclusive goal of monetary policy. Their theory does not explain why it should matter very much.

High inflations pose "stress tests", as it were, of this kind of macro/monetary theory. My friend Daniel Heymann and I (Heymann and Leijonhufvud 1995; Leijonhufvud 1997) decided on behavioural rather than numerical criteria for categorizing inflations. An inflation would be classed as "moderate" if people quoted inflation rates in percent per year, "high" if measured in percent per month, and "hyper" if 30-day estimates were not considered meaningful. Monetary GE models "flunk" the high inflation stress test on a number of counts.

It is an often repeated truth that general equilibrium models do not require money, monetary instruments, or monetary institutions. Money is added on the GE models by obvious artifice and it is safe to say that no one is satisfied by any of the proposed tricks for accomplishing it. From the standpoint of such theory, therefore, it is a surprise to find that domestic money stays in use even at inflation tax rates of 2-3,000\% per annum. It does not perform all the functions that a stable money will perform but it remains in widespread use as an everyday means of payment.

Furthermore, money's role as a unit of account is not essential even in monetary general equilibrium models. Any good in the system could serve just as well. In contrast, the evidence shows that monetary accounting is essential to the monitoring of innumerable principal-agents relationships in a modern economy. The stock market 
provides a striking example. At very high and unstable inflation rates, companies find no way in which to measure their results and to report them in a reliable and understandable manner to the market. When the market is unable to evaluate company performance it goes inactive. Trading in the corresponding shares ceases. Although a variety of accounting and contracting devices are invented during high inflations, none of them proves a good substitute for a stable money.

Third, the commodity space spanned by markets is invariant to inflation in GE models. This too is false. Most intertemporal markets, including all bond markets, simply disappear. The longest maturities denominated in domestic money may be on the order of 4-8 weeks. At the same time, spot markets fragment. A market economy has innumerable arbitrage mechanisms that are such everyday phenomena that we seldom give them any thought. But with prices rising at high and unpredictable rates, such arbitrage turns into risky speculation and traders withdraw from it. As a consequence, the relative price of the same commodity in different locations-even very nearby locations-becomes highly variable.

This is an example of a more general phenomenon of high inflations, namely, that relative prices are far, far more variable than in economies enjoying a fair degree of monetary stability. Some years ago, numerous papers were written on this subject. Virtually all of them supposed that this excess relative price variability arose because, while one set of prices were "flexible" and traced the general inflation more or less perfectly, another set were subject to "menu costs" and those prices would adjust only spasmodically. This supposition, I believe, results from the common prejudice among economists that if anything goes wrong it is because some prices are "sticky". The real problem, instead, is that most prices end up far too "flexible".

Two rather colourful illustrations from Argentinian experience of about twenty years ago help explain what is going on. One concerns the extreme volatility of the exchange rate of the dollar in terms of domestic currency. It would swing by up to $30-40$, even $60 \%$ from one day to the next. This happened because the large financial institutions became unwilling to take positions on the rate and instead withdrew as market makers. All relatively large non-financial firms tried to keep as much of their liquid assets as possible abroad. When, for example, such a firm would bring funds back to pay wages in pesos (or australes, as the case may be), the peso would strengthen abruptly in the absence of a market maker, only to fall equally dramatically again when some other firm sought to transfer funds abroad.

This example has a counterpart at a more humble level. When the economy reached the border of hyperinflation, a number of small shop owners in Buenos Aires shut their shops and posted a sign "Closed for the lack of prices". (This caused bread riots in some quarters of the city). These shop owners had most of their capital tied up in their inventory and had no idea at what prices they might be able to restock tomorrow if they sold today. So, refusing to speculate any further, they closed shop-which is to say, they refused to serve as market makers and to let their inventory serve as a buffer stock for their neighbourhood.

Please note that the disappearance of intertemporal markets, the refusal of market makers to play their usual roles, and the resulting turbulence in relative as well as absolute prices are just different aspects of the social adaptation to extreme monetary 
instability. In this process, all prices are exceedingly flexible ${ }^{4}$ - and the result is utter chaos!

If the authorities are able to reduce the inflation rate and its variability a bit, wholesalers will be able to quote prices for delivery a few days hence; retailers will post their prices and stick to those prices for a day or two; consumers will be able to do some meaningful comparison shopping; prices at different locations will begin to reflect transportation costs - and a coherent price system with some temporal depth and some spatial coverage will reemerge. But some "stickiness" of prices is needed for resource allocation to be at all rational.

\section{The thin end of the "Fat Tail"}

No one would consider prices on the stock exchanges to be "sticky". The October 1987 stock market crash illustrates the point that it is relative speeds of adjustment that matter. I have found Richard Bookstaber's (2007) account of how the crash was triggered particularly instructive. The stock market had gone through three consecutive days of big declines in the week ending Friday, October 16. The managers of portfolio insurance programs started out to reset their dynamic hedges first thing on Monday morning, October 19. This required selling S\&P futures. A massive amount of sell orders flowed in to the Chicago futures market and the price of futures fell rapidly. Induced by the widening gap between the current futures price and the Friday closing prices for the individual stocks, cash-futures arbitrageurs stepped in to buy futures with the intention of shorting the stocks underlying the S\&P index. However, at this point the New York Stock Exchange had not yet opened. When half-an-hour later NYSE did open it was hit by a surge of sell orders. The wave hit a wall. The volume was too large for the specialists to add to inventory so they tried to find buyers by dropping prices. But the equity investors initially were not ready to reevaluate their positions that quickly and later on were frightened off by the very speed with which prices were falling. Thus, concludes Bookstaber (p. 22), there was "a dislocation between the hair-trigger execution of the futures and the ponderous decision making on the cash-equity side, compounded by the insufficient capital of the specialist to bridge the gap..." Rephrasing his point, the specialists did not have the buffer stock capacity to keep the process orderly so as to keep it within its "corridor". The deviation-amplifying process gathered ever more momentum so that "in the last 75 min of the trading day, the Dow dropped ...three times as much .... as it had in any other full trading day in history” (p. 25).

\section{Current state of macroeconomics}

So far, I have tried to persuade you that general equilibrium theory has failed to integrate money in a meaningful way and that, as a consequence, it fails to explain the severe coordination failures characteristic of serious depressions and of high inflations. At the same time, I have argued that orderly markets generally require market

\footnotetext{
4 To be precise, it should be "all the surviving prices are flexible", since a lot of markets have closed down.
} 
makers who hold inventories that act as buffer stocks especially against high frequency shocks and who in this way smooth the path of prices and make them more predictable to other market participants. If the buffer stocks are exhausted or if the market makers withdraw, the result is exceedingly "flexible" prices-but such conditions are detrimental to the functioning of an economy.

I now want to take this argument a bit further and consider the dynamic stochastic general equilibrium (DSGE) model which has been considered the State of the Arts in macroeconomics for quite a few years by now. To be blunt about it, I believe this brand of macroeconomics is now in serious difficulty. It is of very little (if any) help in trying to understand our present troubles and it has more than just a little responsibility for the doctrines of monetary policy and financial regulation that have landed us in these troubles. People working in this vein are now busy adding inflexibilities, transaction costs, and whatever other "imperfections" may come to mind in order to bring the DSGE model in some sort of conformance with the data. Adding epicycles in this manner signals a degenerating research program. In the process, DSGE is losing all the clean-cut radical attractions of what was once the New Classical economics. We are well on our way to a New Neoclassical Synthesis, so help me! This one will be served up with all the dynamic and stochastic trimmings.

To see what has gone wrong, ${ }^{5}$ it is helpful to go back a bit and consider some of the steps by which the profession has arrived at this point.

The Phillips Curve controversy which began in 1967-68 is usually taken to be a watershed in the development of modern macroeconomics, leading to the defeat of "old Keynesian" theory and its replacement by New Classical economics. To avoid misunderstanding, I emphatically agree that the Phillips curve is not stable. Shocks to the system that set its nominal scale adrift will shift it, of that we can be sure. It is an elementary error, however, to conclude that this means that "the long-run Phillips Curve is vertical".

To see this, start with a point made by Keynes himself. He argued that Ricardo had arrived at the conclusion that the rate of interest would adjust so as to coordinate saving and investment over time because he had assumed full employment. In the absence of full employment, the rate of interest would not settle at its "natural" rate (although here I am not using JMK's terminology).

Milton Friedman, in his famous 1967 Presidential address to the American Economic Association (Friedman 1968), in effect turned this argument around. He assumed what Ricardo had concluded and deduced what Ricardo had assumed. He concluded that flexible wages would produce full employment (the "natural" rate of unemployment) because he assumed the financial markets would coordinate the intertemporal decisions of households and firms. If this assumption of Friedman's is granted, one would indeed be led to conclude that the long-run Phillips Curve is vertical.

\footnotetext{
5 Perhaps I should confess from the start that the heterogeneity of agents is not going to play a prominent role in my account! Of course, lack of attention to heterogeneity is often a serious defect of DSGE models. But recent events have shown that too many agents trying to do the same thing at the same time can be truly critical. When all financial institutions try to deleverage simultaneously, for example, the result is a very deep recession. Destabilizing, positive feedback processes are often of this type. And they are missing in general equilibrium models.
} 
It is obvious what Keynes would have answered Friedman, namely, that if planned saving were to exceed investment at the natural rate of unemployment, flexible wages will not bring that rate of unemployment about. However, this argument was not effectively made by Keynesians most of whom were preoccupied with the supposed inflexibility of wages. Instead both Friedman's assumption and his conclusion became embedded in Lucasian monetarism and, after its demise, carried forward by Real Business Cycle theory. Rational expectations in fact provide a more "rigorous" basis for the intertemporal equilibrium assumption than provided by Friedman.

The implications for the labor market are that, given intertemporal equilibrium prices, the more flexible are wages the better. (Note that in theories in the WicksellKeynes tradition, this is emphatically not true). Also, since the Phillips curve is vertical at NAIRU, policy should not try to exploit temporary "inflexibilities".

In financial markets, real rates of interest are determined altogether by real factors, that is, by intertemporal production possibilities and by intertemporal utility of consumption and by risk aversion (think of representative agent models). The implication is that the Central Bank has no power over real rates of return. If it tries to set a money rate of interest different from the equilibrium real rate, $i \neq r^{*}$, the result will be a cumulative Wicksellian inflation or deflation.

The two sets of propositions about the labor market and the financial markets taken together, Friedman (and later his successors) argued meant that monetary policy should be exclusively directed to the goal of price stability. In Friedman's case, this was to be accomplished by following his money stock growth rate rule. If the money growth rate is set too high, the money rate will be transitorily too low and inflation will result. Once expected, of course, the inflation will drive the money rate of interest above the real rate.

Subsequently, as we all know, financial deregulation and a tsunami of financial innovations swept away the hitherto fairly stable relationship between the money stock and nominal income with the result that Friedmanian money growth rules had to be abandoned.

The new Central Banking doctrine became inflation targeting. The theory that it is based on might be defined as "monetarism without money".

\section{DSGE in the light of recent events}

Inflation targeting is an adaptive operating doctrine. The Central Bank never knows what is the exact "natural rate" of interest. It is depending on feedback from the behaviour of the price level. If it creeps above the target range, Bank rate is too low. In the opposite case, too high.

This operating doctrine failed in the United States in the 2002-2006 period. The CPI inflation rate did not move and this misled the Federal Reserve System and made it maintain the federal funds rate far too low for far too long. The result has been asset price inflation and a serious deterioration of credit standards, the consequences of which we are now struggling to contend with.

It is not just the Central Bank's operating procedures that have failed. The failure involves also the theory on which the inflation targeting doctrine was based. The 
proposition that the real rate of interest is determined solely by "real" factors and that the Central Bank cannot affect it is seen to be false.

It is far from the first time that economists have come to rely on an overly simplistic theory of how the complex economic system works. Once again, it is time to rethink our monetary theory.

\section{Conclusion}

The most fascinating problems in macroeconomics to my mind are those indicated by my title: What are the limits to the ability of market systems to function "automatically" and to coordinate economic activities fairly well. What might make the system move beyond those limits? How do we understand its behavior when it is performing very badly? When does it require "stabilization policy" or institutional reforms and what specifically needs to be done in particular circumstances?

In this lecture, I have tried to persuade you of two things. First, that serious macroproblems are not a simple result of inflexibilities of prices and, second, that standard economic theory does not provide sufficient understanding of the role of money and of monetary institutions in the economy.

I promised in my introduction to explain why I think the development of agentbased methods of modelling is important. The reason, as I think you might now agree, is that there are severe limits to what can be achieved with analytical methods in trying to understand the dynamic behavior of the complex system of a modern market economy.

Open Access This article is distributed under the terms of the Creative Commons Attribution Noncommercial License which permits any noncommercial use, distribution, and reproduction in any medium, provided the original author(s) and source are credited.

\section{References}

Bookstaber R (2007) A demon of our own design: markets, hedge funds, and the perils of financial innovation. Wiley, Hoboken

Clower RW (1967) A reconsideration of the microfoundations of monetary theory. Western Econ J, December [reprinted in Donald A. Walker (ed), Money and markets: essays by Robert W. Clower. Cambridge University Press, Cambridge (1984)]

Friedman M (1968) The role of monetary policy. Am Econ Rev, March

Heymann D, Leijonhufvud A (1995) High inflation. Oxford University Press, Oxford

Leijonhufvud A (1997) Macroeconomics and complexity: inflation theory. In: Arthus B, Durlauf S, Lane D (eds) The economy as an evolving complex system, vol II. Addison-Wesley, New York

Leijonhufvud A (1973) Effective demand failures. Scandinavian Econ J, March [reprinted in Leijonhufvud, Information and Coordination, Oxford University Press, Oxford (1981)]

Maćkowiak B, Smets F (2008) On implications of micro price data for macromodels. Paper presented at Federal Reserve Bank of Boston Conference, Chatham, MA, June 9-11 